sciendo Порівняльна професійна педагогіка 9(1)/2019 Comparative Professional Pedagogy 9(1)/2019

DOI: $10.2478 /$ rpp-2019-0007

$\mathrm{PhD}$ in Philology, Senior Research Fellow, MARIANNA MARUSYNETS

Foreign Pedagogical Systems and Adult Education Department, Ivan Ziaziun Institute of Pedagogical and Adult Education of the NAES of Ukraine

Address: 9 M. Berlinskoho St., Kyiv, 04060, Ukraine E-mail: marusynetsm@ukr.net

\title{
CONTINUING EDUCATION AS A FACTOR OF PERSONALITY SOCIALIZATION (IN THE CONTEXT OF AUSTRIA'S EXPERIENCE)
}

\begin{abstract}
The article analyzes the concept "continuing education" determining its priorities and specifics as compared to other forms of learning. It is established that the subject of continuing vocational training is an adult who has acquired a certain life and professional experience. It is identified that the need for lifelong learning arises from the fact that to some extent an adult has knowledge and skills not sufficient to carry out their professional or other tasks. Self-motivation for new knowledge appears when facing complex problems, and when past experience does not allow solving them successfully. The specifics of lifelong education are connected with the psychological characteristics of an adult, namely: self-awareness of oneself as an independent personality with a critical view on any control attempts even if it not expressed verbally; the accumulation of a considerable life, social and professional experience that shapes the outlook, and in this respect creates a background for the evaluation of any incoming information; motivation for learning lies in a pragmatic approach - an adult seeks to solve their life problems with the help of learning (career, communication, leisure, etc). In contrast with a student or a pupil, an adult tries to apply the acquired knowledge as soon as possible or to obtain satisfaction from the learning process itself; their perception is invariably accompanied by an emotional evaluation of information when the brain attempts to "block" any information provoking negative emotions (even if it is just hunger, an uncomfortable sitting or stuffiness). Austria is pursuing the policy on continuing education, including several ministries and the Ministry of Education and Women's Affairs. However, this kind of education is not free from shortcomings: for some adults, it is a way of organizing leisure: spending time usefully, having a rest from work, or the lack of learning goal awareness.

Keywords: adult education, continuing education, personality socialization in the conditions of continuing education, adult education system of Austria.

\section{АНОТАЦІЯ}

У статті проаналізовано сутність поняття освіта впродовж життя, визначено ї̈ пріоритети та специфіку з поміж інших форм навчання. Встановлено, що суб'єктом неперервного професійної навчання є доросла людина, яка досягла певного життєвого й професійного досвіду. Встановлено, що потребою в навчанні упродовж життя є те, що до певної міри дорослій людині для вирішення ї̈ професійних або іншого роду завдань недостатній наявний у неї запас знань і умінь. Поява самомотиваиії до нових знань з'являється тоді, коли перед нею виникають складні проблеми, а минулий досвід, не дозволяє їй вирішувати їх успішно. Специфіка
\end{abstract}


sciendo Порівняльна професійна педагогіка 9(1)/2019 Comparative Professional Pedagogy 9(1)/2019

освіти упродовж життя також обумовлена й психологічними особливостями дорослої людини, а саме: усвідомлення себе самостійною, самокеруючою особистістю, яка критично ставиться до будь-яких спроб управління, навіть якщо вголос цього не висловлює; накопичення чималого запасу життєвого, сочіального і професійного досвіду, який формує ї̈ світогляд, $i$ з огляду на ие очінює будь-яку інформацію, щзо поступає; мотивачія до навчання полягає в прагматичному підходi - прагне за допомогою навчання вирішити свої життєві проблеми (кар'єра, спілкування, дозвілля тощо); на відміну від учня/студента прагне до невідкладного застосування здобутих знань або до отримання задоволення від самого прочесу навчання; його сприйняття незмінно супроводжується емочійним оиінюванням інформації, коли мозок прагне "заблокувати" будь-яку інформачію, що супроводжується негативною емочією (навіть якщо ие просто відчуття голоду, незручне сидіння або нестача свіжого повітря). Австрія проводить політичну стратегію щодо навчання упродовж життя, включаючи декілька міністерств й Міністерство освіти і жіночих справ. Водночас, такий вид освіти не облишений і недоліками: для окремих суб'єктів такий вид освіти є способом організаиії дозвілля: провести час з користю, відпочити від роботи, або немає усвідомлення мети навчання.

Ключові слова: освіта дорослих, неперервна освіта, соціалізація особистості в умовах неперервної освіти, освітня система дорослих в Австрії.

\section{INTRODUCTION}

Nowadays continuing education or life-long education as a strategic idea does not draw any considerable objections. It has a significant number of proponents not only in European countries but also in Ukraine. Despite being in demand, there is no specific content on life-long education in pedagogical science and practice. However, the today's model of continuing education in European countries provides an opportunity for everyone to realize their abilities by learning throughout their lives. The latter forms the backbone of the life-long education strategy and prospects for its development.

\section{THE AIM OF THE STUDY}

The aim of the study is to substantiate and reveal strategic directions of the education development in Austria.

\section{THEORETICAL FRAMEWORK AND RESEARCH METHODS}

The research theoretical framework is grounded upon the methodology fundamentals in comparative pedagogy (N. Abashkina, B. Vulfson, V. Klarin, M. Leschenko, Z. Malkova, V. Pylypovskyi, L. Pukhovska, etc.); the conceptions of education, upbringing, and training (V. Andrushcenko, I. Beh, S. Goncharenko, I. Ziaziun, V. Kremin, O. Savchenko); the conceptual provisions of life-long education organization and development (O. Anishkenko L. Lukianova, N. Nychkalo, O. Ogienko), the theory of personal and professional-pedagogical development (V. Luhovyi, S. Maksymenko, V. Moliako, O. Piekhota, V. Semychenko, S. Sysoieva).

The research methods are as follows: analysis and synthesis, abstraction and concretization, classification and systematization of theoretical and empirical data, comparative analysis of the phenomena and facts connected with "adult learning" and its organizational and educational support in the countries of Austria.

STATEMENT OF BASIC MATERIALS. Adult education occupies an independent position in the Austrian system both quantitatively and qualitatively, including various forms: teaching, group supervision, counselling, guidance, education management, and library services. 
Adult education" or "Continuing vocational training" is determined from the point of view of age and educational background. If any initial (vocational) education or training has been completed and is followed by another educational stage, then it is described as adult education, continuing vocational training or further education.

The subject of continuing vocational training is an adult who has acquired a certain life and professional experience. The specifics of life-long education are connected with adults' psychological characteristics. In this sense, psychologists distinguish five main features characterizing the adult motivation to study throughout their lives:

1. Awareness of oneself as an independent personality with a critical view on any control attempts even if it not expressed verbally;

2. The accumulation of a considerable life, social and professional experience that shapes the outlook, and in this respect creates a background for the evaluation of any incoming information;

3. The motivation for learning lies in a pragmatic approach - an adult seeks to solve their life problems with the help of learning (career, communication, leisure, etc.);

4. In contrast with a student or a pupil, an adult tries to apply the acquired knowledge as soon as possible or to obtain satisfaction from the learning process itself;

5. Their perception is invariably accompanied by an emotional evaluation of information when the brain attempts to "block" any information provoking negative emotions (even if it is just hunger, an uncomfortable sitting or stuffiness) (Agapova, 2003).

Thus, life-long education differs from the rising generation education in its values and motives, goals and objectives, content and forms of organization, methods of control and evaluation, and obtained results. S. Vershlovskyi (2002), analyzing the motives of adult education, notes that "first of all, an adult learns guided by pragmatic motives. If they already have the necessary knowledge sufficient for solving problems, then there is no need to go beyond the acquired life and professional experience".

An important advantage of adult education is the fact that to some extent an adult has some knowledge and skills sufficient to carry out their professional or other tasks. The need for new knowledge appears when facing complex problems, and when past experience does not allow solving them successfully. In such a way the need for new knowledge is formed. It is the new knowledge that introduces a person into another social reality the peculiarity of which lies in the search for a rational and innovative solution to problems. Then, it becomes relatively significant, that is, an element of the new experience, until the next problem presents a person with the need to re-review the available stock of knowledge, and critically evaluate the system of values.

The value of adult education is determined not only by its practical significance, its ability to meet the needs of different fields of activity but also by an altruistic attitude towards it. It is widely believed that education presents value in itself since knowledge for the sake of knowledge is not stimulated by any factors. However, by engaging a person into educational activities it can be achieved their qualitative transformation. In this sense not only adults ' practical experience, but also the development of knowledge together with the learning process itself becomes meaningful. In this context, an adult seems to break from bonds of socially determined learning. Cognitive, creative processes are gradually becoming independent from adults' daily routine, therefore, getting replaced by "self-motivation".

N. Myronchuk (2018) claims self-motivation to be a factor providing adults with the possibility to retain fitness for work, as there is an internal process of achieving or maintaining the status of the subject controlling an individual's life activities. The 
sciendo Порівняльна професійна педагогіка 9(1)/2019 Comparative Professional Pedagogy 9(1)/2019

motivation for achievement and success inspires people to seek new ways of using their energy, abilities and efforts in professional activity. A positively motivated person shows readiness to successfully carry out professional duties, produce new, bright ideas, show initiative, be involved in a creative endeavor and enjoy finding solutions.

Since 2011, Austria has been pursuing the policy on lifelong learning (LLL: 2020). Several ministries, including the Ministry of Education and Women's Affairs file annual reports presenting the achieved results on adult education. They are:

1. Federal Ministry of Education and Women's Affairs (Department of Adult Education): General adult education and schools for employed persons

2. Federal Ministry of Science, Research and Economy: University education, onthe-job training

3. Federal Ministry of Labour, Social Affairs and Consumer Protection: further education related to the job market

4. Further ministries involved in further education: Federal Ministry of Health, Federal Ministry of Agriculture, Forestry, Environment and Water Management, Federal Ministry of Finance, Federal Ministry of the Interior and Austrian Foreign Ministry (European Association for the Education of Adults, 2011).

Adult education in Austria is also regulated by the provinces and municipalities. The municipalities are responsible for community education or may participate in commonbenefit institutions for further education. The provinces take care of the funding of adult education (mostly funding of participants' fees).

The social partners are also public bodies responsible for adult education. They have authority over institutions for further education and are involved in making collective agreements with providers of adult education (professionals/employees and institutions/ employers).

\section{Relevant umbrella associations and national (service) organizations}

The ten associations of adult education providers in accordance with the Adult Education Promotion Act are combined into an umbrella association: KEBÖ (short for "Konferenz der Erwachsenenbildung Österreichs" - conference of adult education in Austria). KEBÖ was founded in 1972 and is a partner of the Federal Ministry of Education and Women's Affairs in implementing focus points of adult education policy. KEBÖ is made up of the following ten organisations and associations:

- Working group of Austrian educational centres (Arbeitsgemeinschaft Bildungshäuser Österreich - ARGE BHÖ);

- Austrian vocational training institute (Berufsförderungsinstitut Österreich - BFI);

- Association of public libraries in Austria (Büchereiverband Österreichs - BVÖ);

- Forum for catholic adult education in Austria (Forum Katholischer Erwachsenenbildung in Österreich - FORUM);

- Rural continuing education institute (Ländliches Fortbildungsinstitut - LFI);

- Network of Austrian adult education institutes (Ring Österreichischer Bildungswerke - RÖBW);

- Austrian Economic Society (Volkswirtschaftliche Gesellschaft Österreich - VG-Ö);

- Association of adult education for Austrian trade unionists (Verband Österreichischer Gewerkschaftlicher Bildung - VÖGB)4

- Association of Austrian Adult Education Centres (Verband Österreichischer Volkshochschulen - VÖV);

- The Austrian Chamber of Commerce's Institute for Economic Promotion (Wirtschaftsförderungsinstitut der Wirtschaftskammer Österreichs - WIFI). 
sciendo Порівняльна професійна педагогіка 9(1)/2019 Comparative Professional Pedagogy 9(1)/2019

There are two more associations which are mentioned in the Promotion Act but are not members of KEBÖ:

- Austrian Federation of Europe Houses (Österreichische Föderation der Europahäuser - ÖFEH)

- Association of the scientific societies of Austria (Verband der wissenschaftlichen Gesellschaften Österreichs - VWGÖ) (Friesenbichler, Hackl, 2015).

Let's briefly outline their content and functions.

The Working group of Austrian educational centres (Arbeitsgemeinschaft Bildungshäuser Österreich - ARGE BHÖ). Educational institutions include institutions for extracurricular education and adult education. They are supervised by a teaching team and have modern well-equipped classrooms and club classes, as well as accommodation and recreational facilities and nutrition. The program includes the following directions: political, professional artistic education, religion, craft skills, gymnastics, and integrative events. The main forms of training are seminars, courses, conferences. The main attention is paid to the long-term activity forms in order to construct the professional's personality.

The Forum for catholic adult education in Austria (Forum Katholischer Erwachsenenbildungin Österreich) - a federal adult education organization. It is one of the main educational organizations in Austria that meets the interests of more than 60 member organizations in providing educational services, offering them curricula such as the program of the person's education, family education, socio-political education, women's education, religion and theology, as well as education in the field of art and culture. Representatives of the forum, basically, work relying on volunteers` help.

Public higher education institutions (Volkshochschule commonly abbreviated to VHS) by their origin and activities are related to the Scandinavian countries` institutes that offer various educational services: courses in various spheres of professionals' selfdevelopment involving the study and improvement of foreign and native languages; informal courses in art and music, politics and information technology, everything satisfying the interests of participants. At the federal level, sponsors of higher educational institutions can be the municipality and the Labor Chamber, but the vast majority of revenue comes from payments made by individual students. Launched in Austria in the nineteenth century, they have a good reputation and are well known in their communities.

The Network of Austrian adult education institutes (Ring Österreichischer Bildungs werke - RÖBW) coordinates and facilitates cooperation between the participants, the exchange of experience, general political education, its participants commitment; it consists of the Austrian National Education (VÖvbw) and cooperation, the taskforce of the Protestant Educational Institutions (Aebw). The educational program includes the study of society`s social and economic policy, economy, ecology, health, music education, development policy, religion and theology, education for parents. Forms of training are courses, meetings, seminars, discussions, reports, educational weeks, and educational trips.

The Association of public libraries in Austria (Büchereiverband Österreichs - BVÖ). Austrian public libraries are one of the main institutions of adult education. Within the available financing, they provide free access to various types of information in the public libraries' media that cover the following areas: science, art, literature, politics; recreation and entertainment media; audiovisual media - multimedia. Public libraries are increasingly becoming communication centers, where readings, concerts, discussions and literary presentations are organized. The work of the social library is another important task. Currently, more than 10.6 million media are available in 2451 public libraries, and more 
sciendo Порівняльна професійна педагогіка 9(1)/2019 Comparative Professional Pedagogy 9(1)/2019

than 1.1 million readers take 16.9 million media annually. In Austria, about $90 \%$ out of approximately 9500 librarians work on a voluntary basis (Statistik Austria, 2018).

The organizational structure. The Association of Austrian Books is an umbrella organization of public libraries representing their interests. It is composed of public libraries as individual members and the library department's umbrella organization of the Australian Confederation of Trade Unions and the Österreichische Bibliotheks Werk. The Association organizes and develops the education and training of public library workers, issues publications on the library industry, assists in the construction and reorganization of libraries, organizes central purchases of library material, monitors the specialized library, and compiles the comprehensive annual statistics of Austria.

The Austrian Economic Association (Volkswirtschaftliche Gesellschaft Österreich$V G O ̈$ ), founded more than 50 years ago, is involved in the development of integration programs linking formal education and the business world. Partners and its regional network are involved at the local, national and European levels in the facilitation of enterprise development and satisfaction of the countries' economic needs. The main focus is put on students and young people's training, as well as on those who are interested in contributing to the development of society.

The Association of adult education for Austrian trade unionists (Verband Österreichischer Gewerkschaftlicher Bildung - VÖGB) is responsible for the training of employees who are members (workers) of advisory councils. In the learning process they get the skills and knowledge necessary to carry out professional tasks in their companies. Such an approach ensures the training and professionalism development of employees and trade unions. Representatives of the associations offer workshops and events for representatives of companies that focus on important topics such as social and economic policies, media, law, communication, languages, and workforce representation in the councils, computer applications, and issues of workers' mobility in the European Union.

Special courses are provided to the following target groups: members of the European Workers' Councils, health and safety officers, representatives of supervisory councils, jurors, youth council members, social security representatives, educational and cultural institutions, social workers, volunteers working with the disabled and women managers. Forms of training include courses, reports, seminars, workshops, meetings, exhibitions, performances, education trips.

Non-Governmental Organisations ( $N G O s)$.

As it is the case in most European countries, non-profit adult education is provided by a variety of voluntary and non-governmental organizations, religious, legal institutions that provide educational services to specific groups of people (for example, women, artistic organizations, etc.).

In Austria, large non-for-profit adult education institutions are members of the organization "the Austrian Adult Education Conference, the organization of nongovernmental adult education providers", which includes the Berufsförderungsinstititut Österreich (BFI), the Austrian Economic Cooperation Institute, the Economic Chamber (Wirtschaftsförderungsinstitut WIFI) comprised of all employers and other "informal" providers (Federal Ministry of Education and Women's Affairs, 2018).

At the same time, many respondents revealed the need for education as a way of organizing leisure: spending time usefully, having a rest from work. Despite such goals being mentioned much less frequently as compared to professional growth, they should also be taken into account in designing the content of continuing education programs for adults. 
sciendo Порівняльна професійна педагогіка 9(1)/2019 Comparative Professional Pedagogy 9(1)/2019

It is interesting to note that most respondents are not aware of the learning goals. Usually these are people who were encouraged to upgrade their skills by superiors. Therefore, the need for study is treated as a waste of time. It should be stressed that during their studies, the negative attitude is dramatically changed, and at the end some of learners even manifest the desire to participate in some other educational programs. This fact allows for the conclusion that there exist some barriers that impede the formation of the adult's need for continuing education and training in general.

The category "psychological barrier" in this sense is interpreted in the following ways:

- mental state that manifests itself as inadequate passivity, which impedes the performance of some actions (Bodalev, 1998);

- motive that creates a barrier to certain activities, in particular, to communication with a particular person or a group of people (Kodjaspirova, 2005);

- "internal obstacle" which is the most frequent cause of internal conflicts (Kashapov, 2003).

\section{CONCLUSIONS}

In summary, it is worth noting that the subject of continuing vocational training is an adult who has acquired a certain life and professional experience. The specifics of lifelong education are connected with adults 'psychological characteristics and the need for new knowledge facing complex problems, and when past experience does not allow solving them successfully. It has been found that lifelong education differs from the rising generation education in its values and motives, goals and objectives, content and forms of organization, methods of control and evaluation, and obtained results. In further publications it will be substantiated the structural components of adult education in Austria together with the specification of their didactic and technological support.

\section{REFERENCES}

1. Agapova, O. (2003). Lessons for adults: A manual for those who work in the adult education system. Saint Petersburg: Publishing house "Tuscarora".

2. Vershlovskyi, S. (2002). Adult Education: Experience and Problems Saint Petersburg : IVESEP, Knowledge.

3. Myronchuk, N. (2018). Self-motivation as a component of the teacher's selforganization in professional activity. Education problems: the collection of research papers, $88(2), 65-74$.

4. European Association for the Education of Adults. (2011). Country Report on Adult Education in Austria. Retrieved from: https://eaea.org/country/austria/

5. Friesenbichler, B., Hackl, W. (2015). Adult Education in Austria. Retrieved from: https://keb-deutschland.de/adult-education-in-austria/

6. Statistik Austria. (2018). Adult education, further training, lifelong learning. Retrieved from: http://www.statistik.at/web_en/statistics/education_culture/adult_education further_training_lifelong_learning/index.html

$\overline{7}$. Federal Ministry of Education and Women's Affairs (BMBF). (2018). Retrieved from: http://greenet.ea.gr/content/federal-ministry-education-and-womens-affairs-bmbf

8. Bodalev, A. (1998). Top in the development of an adult: characteristics and conditions of achievement. Moscow: Flint.

9. Kodjaspirova, G. (2005). Dictionary on pedagogy. Rostov n/d.: Ed. Center "Mart".

10. Kashapov, M. (2003). Theory and practice of conflict resolution. Short dictionary. Moscow-Yaroslavl: Remder. 